\title{
Sun-Dried Bilimbi (Averrhoa Bilimbi L) as an Additional Income For Housewives In Ujong Tanoh Darat Village, Meureubo Sub- District, Aceh Barat Regency, Aceh
}

\author{
Rusdi Faizin, Raidayani, Yoga Nugroho, Irma Yanti \\ Agribusiness Department, Faculty of Agriculture, Universitas Teuku Umar \\ rusdi.faizin@utu.ac.id
}

\begin{abstract}
This study aims to calculate the additional amount of housewife income in Ujong Tanoh Darat Village, Meureubo District, West Aceh Regency as a producer of sun-dried bilimbi. Respondents in this study were ten producers in Ujong Tanoh Darat Village. Data collection techniques by observing and interviewing in detail related to the analysis of sundried bilimbi producer income. The data analysis method uses cost analysis, production revenue, production income, and revenue cost ratio $(R / C)$. From the results of data processing in this study, it found that the average income earned by producers was $R p .300,550$ per cycle, the average producer income was $R p .602,000$ per cycle and the average production cost incurred by producers is Rp.301,499 per cycle, and the $R$ per $C$ ratio obtained is 1.9, greater than 1 meaning the sun-dried bilimbi producer business in Ujong Tanoh Darat Village, Meureubo District West Aceh is feasible.
\end{abstract}

Keywords: housewives additional income; revenue cost ratio

\section{Introduction}

Bilimbi (Averrhoa Bilimbi L) is the raw material in making sun-dried bilimbi. Sun-dried bilimbi is a very traditional and sensational spice in Aceh. Its sour taste makes the dishes have characteristics that are very different from dishes from other regions. The sour taste came from a very high level of acids and salts. Sun-dried bilimbi contains $6.08 \mathrm{~g}$ per $100 \mathrm{~g}(6.08 \%)$ acid and $27.4 \%$ salt, the acid and salt content of sun-dried bilimbi is high enough to inhibit the decay process by microorganisms and provide adequate food preservation (Husin, 2016).

West Aceh Regency is one of the regency in Aceh province where the community still produces sun-dried bilimbi. There is not much sun-dried bilimbi processing because there is no specific cultivation of bilimbi trees, so people only process sun-dried bilimbi by using trees in the yard of their house. In Ujong Tanoh Darat village, the production of sun-dried bilimbi is carried out by housewives as an addition to their family income. The additional income has a role in fulfilling the needs and improving the family's welfare.

Ujong Tanoh Darat Village is a village that has an essential role in the food crops and plantation sub-sector, especially for the Meureubo sub-district, which contributes significantly in terms of increasing income (Ujong Tanoh Darat Government Database, 2018). Based on the data, in Meureubo Sub-District, West Aceh Regency, the most bilimbi trees located in Ujong Tanoh Darat Village, which are around 35 trees owned by ten sun-dried bilimbi producers. Processing bilimbi into sun-dried bilimbi takes about 34 days. According to Hayati (2002), the best bilimbi fruit is harvest at the age of 34 days after the flower blooms. However, before the peak harvest comes, a small amount of the prime bilimbi can be harvested. Some of the producers process it into sun-dried bilimbi for their family consumption, others, use fresh bilimbi as a spice for cooking. Based on this, the sun-dried bilimbi business can be categorized as a semi-commercial business. Willeki (2017) states that semi-commercial farmers are subsistence farmers who set aside their crops for sale.

On the other hand, sun-dried bilimbi, which is a unique spice from Aceh, has not been in demand by the industry. There are no businesses that produce large quantities of sun-dried 
bilimbi in Aceh. This study aims to determine the amount of additional income received by housewives in the village of Ujong Tanoh Darat from producing sun-dried bilimbi. Some limitations, such as the sustainability of raw materials and low product prices, will affect the revenue.

\section{Research Methods}

The research was conducted from March 14 to April 18, 2019. The determination of the location of the study was carried out intentionally (purposive sampling) with the consideration that the Ujong Tanoh Darat Village, Meureubo sub-district, West Aceh Regency is one of the villages producing sun-dried bilimbi. This study used a saturated sampling method. Primary data related to the characteristics of respondents, such as the respondent's name, age, sex, education, dependents, and the number of bilimbi trees owned, were taken from ten respondents who run a sun-dried bilimbi processing business. Also, secondary data was obtained from the Central Statistics Agency and village offices in West Aceh Regency.

In this study, income was obtained by subtracting the Total Revenue (TR) by the Total Cost (TC). TR is the result of multiplying the amount sold with the market price while the total cost (TC) during the production process is obtained by adding up the fixed costs (FC) and variable costs (VC). The revenue cost ratio was also calculated to determine the feasibility of a sun-dried bilimbi processing business in the village of Ujong Tanoh Darat.

\section{Discussion}

Average housewives who were producing sun-dried bilimbi are 40 years old. This age is classified as a productive age so that a business orientation to produce sun-dried bilimbi in Ujong Tanoh Darat Village, Meureubo sub-district, West Aceh Regency is still possible. According to (Soeharjo and Patong, 1973) states that the age of farmers affects the physical ability to work and way of thinking, younger farmers usually tend to be more aggressive compared to older farmers, besides that age also affects a farmer in managing his farming business. Based on the results of interviews with respondents, the sun-dried bilimbi business is a side job conducted by respondents to obtain additional income. The level of education possessed by the respondents were two high school graduates, one junior high school graduates, five elementary school graduates, and two non-educated graduates. That level of education falls under the low category so that the production of sun-dried bilimbi is stagnant and lack of innovation. Based on the experience aspect, producers of sun-dried bilimbi can be categorized as an expert. However, the lack of education and entrepreneurial spirit, and also the lack of support from various other parties have caused their products to be used only to fulfill their daily needs and have not been able to be marketed to other regions. Four respondents have three bilimbi trees, while the six other respondents have five trees.

The processing of sun-dried bilimbi starts with harvesting, washing, softening, salting, and drying. One harvest cycle lasts for 34 days. First, fresh bilimbi fruits are harvested, with the average producer having four bilimbi trees, in one harvest can reach approximately 250 to $300 \mathrm{~kg}$. Fresh bilimbi then washed with clean water. The respondents had two ways to soften the bilimbi. First, the bilimbi was boiled until the color turns to yellowish, and then dried under the sun in the next day, or second, the bilimbi was soaked for 48 hours (two nights) and then also dried under the sun in the next day.

When bilimbi has softened, the next step is giving 3 or 4 packs of salt for 30 minutes until the salt distributed evenly. Each pack of salt bought for Rp. 1,000. The salting process is performed repeatedly with one or two days intervals while drying under the sun for 10 hours per day with a plastic pad and took out for 3 to 4 days, depending on the right or bad weather. When it is dry, the sun-dried bilimbi production process is complete and then stored in a 
storage jar.

Fixed costs incurred in processing sun-dried bilimbi amounted to Rp 805,000, which included the cost of purchasing two buckets of Rp.79,000 per unit, purchasing four jars of Rp.113,500 per unit, purchasing a water pump machine of Rp.671,000 per unit and purchasing a scale for Rp. 200,000 per unit. The primary raw material, bilimbi, is obtained directly by producers from trees around their house, so the cost of procuring the bilimbi does not include in the purchase of raw materials. The market price for bilimbi is Rp. 10,000 per $\mathrm{Kg}$. In the process of making sun-dried bilimbi, the producers also use salt as additional raw materials, plastic for drying, and plastic bags for packing.

Each production cycle of sun-dried bilimbi can use 18 to 25 packets of salt. The salt price is Rp. 1000 per pack. The price of drying plastic is Rp. 14,000 per meter, the plastic used for drying is 5 to 6 meters. The plastic used can be used many times and can be stored for the next production process. The price of a plastic bag for packing is Rp. 5,000 per piece. The fixed costs incurred in the sun-dried bilimbi business, such as transportation costs consisting of gasoline is Rp. 10,000 to Rp. 20,000, while the water used is from a self-owned water pumping machine at the cost of Rp. 3,000 to Rp. 4,000 per cycle.

The labor is persons who work in the process of picking fresh bilimbi into producing sun-dried bilimbi. Ten people were used for the process of washing, soaking, salting, and drying. Costs incurred are Rp. 853,000 per production cycle.

Variable costs incurred by producers consisted of purchasing salt, plastic for drying, plastic for packing, gasoline, and water as much as Rp. 1,628,000 and labor costs are Rp.853,000. Labor costs are calculated to pay labor that comes from within the family. Meanwhile, the fixed costs consist of depreciation costs for buckets, storage jars, water machines, and scales as much as Rp.533,499, so the total cost incurred by the producer are Rp.3,014,499,

The total revenue from sun-dried bilimbi business in one harvest season is Rp. 6,020,000 with the sale price per kilogram of sun-dried bilimbi Rp. 20,000. Based on revenues and costs incurred in producing sun-dried bilimbi, had an $\mathrm{R} / \mathrm{C}$ ratio of 1.9, this means that every one rupiah of the cost incurred will generate income as much as one point nine rupiah.

\section{Conclusion}

Based on the findings, it can be concluded that the total amount received by the producer from making sun-dried bilimbi for each cycle (34 days) are as follows:

1. The average net income earned on the scale of a semi-commercial sun-dried bilimbi business is 300,550 rupiah per cycle

2. The average revenue obtained is 602,000 rupiah per cycle

3 . The average production cost spent by producers in the process of making bilimbi into sun-dried bilimbi is 301,499 rupiah cycle

4. The $\mathrm{R} / \mathrm{C}$ ratio is 1.9 , greater than one, which means that the semi-commercial sundried business is worth continuing.

This research also produced several recommendations, such as:

1. Producers need to take notes related to the process of making sun-dried bilimbi in order to find out whether the business had affected their family income.

2. Producers are expected to add more value to the sun-dried bilimbi product by making a more hygienic and cleaner pack so that the taste of sun-dried bilimbi does not change and last long.

3. The regional government should be able to give attention to the producers of sundried bilimbi to help improve the standard of living of the producers. 
Budapest International Research in Exact Sciences (BirEx) Journal Volume 2, No 2, April 2020, Page: 184-187 e-ISSN: 2655-7827 (Online), p-ISSN: 2655-7835 (Print) www.bircu-journal.com/index.php/birex emails: birex.journal@gmail.com

\section{References}

Arzal, Saiful. (2014). Analisis Tingkat Pendapatan Petani Garam Di Kabupaten Jeneponto Sulawesi Selatan \{Skripsi\}.Fakultas Ekonomi dan Bisnis: Universitas Hasanuddin.

Dumairy. (2004). Matematika Terapan Bisnis Dan Ekonomi. Kanisius:Yogyakarta.

Hayati, Rita. (2002). Kajian Penggaraman dan Pengeringan Belimbing Wuluh (Averrhoa Bilimbi L.) dalam Pembuatan Asam Sunti dari Aceh. Tesis: IPB.

Husin, Hasanuddin. (2016). Formulasi dan Karakterisasi Saos Asam Sunti Dengan Penambahan Maizena_Tesis.UGM: Yogyakarta.

Soeharjo and Patong. (1973). Sendi-sendi Pokok Limu Usaha Tani. Departemen Ilmuilmu Sosial Ekonomi Fakultas Pertanian Institut Pertanian. Bogor

Thamrin, Muhammad, et al. (2013). Analisis Usahatani Ubi Kayu \{jurnal\}.UMSU: Medan.

Willeki. (2017). Manajemen Usaha Pertanian.Faperta:UGM. 